\title{
An Evaluation of the Impact of Business-To-Customer (B2C) Logistics Service Quality (LSQ) on Customer Satisfaction in Nigeria
}

\author{
Adebayo, I. T. ${ }^{1}$ \\ ${ }^{I}$ (Department of Transport Management, Faculty of Management Sciences/ Ladoke Akintola University of \\ Technology, Nigeria)
}

\begin{abstract}
This paper provides empirical results as regards the impact of LSQ and its constitutive elements as potential drivers for customer satisfaction from the B2C perspective in Nigeria as opposed to the usual Business-Business (b2B) approach. Data from 211 customers were analyzed using Multiple Regression Analysis and the Kruskal-wallis Test. The results revealed that all the operational dimensions of LSQ evaluated in the study influenced customers' satisfaction. Furthermore, there existed a significant difference in the customer satisfaction level across the different online stores.
\end{abstract}

Keywords: B2C, competitiveness, customer satisfaction, $L S Q$, online retailer

\section{Introduction}

The emergence of Internet has changed the business landscape with the evolution of online retailing which has now become the latest way of buying items by some shoppers in Nigeria thereby increasingly gaining prominence. Regardless of its relatively nascent stage, Nigeria's online retail industry is already fiercely competitive with several players coming into action whilst offering a full range of products, from mobile phones to fashion, household appliances, groceries etc.

Internet has not only had an important impact on consumers' ordering processes, making it cheaper and faster and transcending time and geographical constraints, but has also had a significant impact on the business model of physical retail stores. Thus, the establishment of the Internet has created enormous potential business opportunities for e-commerce [1].

With the rapid development of e-commerce, customer demand for diversity and timeliness has also increased, in fact, B2C e-commerce business lead higher requirement for logistics service [2]. But, as competition in the business environment is constantly increasing, the ability of companies to understand their customers and ensure their satisfaction with the goods and services provided is becoming more and more significant. Organizations however often focus on external issues related to customer service and satisfaction while neglecting the key internal issues such as logistics. Nevertheless, key internal issues can also play a vital role in facilitating and/or hampering the desired levels of customer satisfaction. This is especially true in the online retailing business as it is becoming more globally recognized coupled with the fact that each customer has different levels of service requirements. Thus, many organizations are striving to a point in which they can be able to meet their customers' wants satisfactorily.

Customer satisfaction however, has been studied in different directions, from measurement to its relationships with other business aspects. The satisfaction construct has been conceptualized, measured and tested for decades in the literature in various industries and contexts [3], [4], [5]. Therefore, the concern about logistics service under B2C E - commerce, is no longer only making a movement from the supplier to the buyer, but also pursuit logistics service in a short time, with flexible service, and high value-added services. Therefore, the quality of logistics distribution has become more and more important to the development of B2C electronic commerce [6].

With more studies being conducted from the business-to-business (B2B) approach there has been little work undertaken from the consumer's perspective, i.e. a business-to-consumer (B2C) approach, which is important for two reasons. Firstly, a shopper represents a productive or operant resource $[7 ; 8]$ as an important downstream supply chain member or logistician, carrying out logistics activities and tasks, weighing up LSQ with economic and non-economic costs (burden, endeavours, inconvenience), confronted with typical supply chain decisions such as outsourcing logistics tasks - via home delivery and electronic shopping - or internalize them - via store-based, traditional shopping $[9 ; 10 ; 11]$. In other words, the consumer represents the final link in the point-of-origin to point-of-consumption definition of logistics [12]. Secondly, LSQ activities directed towards the consumer or shopper, which we term LSQS, also act along a marketing axis: i.e. satisfaction and loyalty both on transaction-specific and cumulative levels [13] are not only influenced by product quality elements, but also by service-related dimensions building up the overall shopping experience. LSQS seems to be an important element in this context, influencing shopper satisfaction and loyalty which are two major variables in marketing research as they guarantee the company's competitive advantage [14]. 
With a dearth of studies on LSQ and the impact on customer satisfaction in Nigeria in the online retailing business, it is therefore imperative that a study be conducted to examine the impact of LSQ on customer satisfaction as well as identify the specific dimensions of LSQ that mainly contribute to the customers' satisfaction. Finally, the study intends to know whether there is a significant difference between the levels of customer satisfaction using different online stores.

\section{Methodology}

The population of the study is infinite, hence the Krejcie and Morgan Test was used to select the sample size. Thus, a sample size of 384 was taken. Non-probabilistic sampling technique with a combination of purposive and convenient sampling methods was employed to get response from the study participants. Data were collected from customers who bought products from the online retail shops in Nigeria over time and accepted to answer the survey questions. Measures for all variables were constructed in accordance with the existing scales in the literature upon which a survey instrument was created. The questionnaire was structured on 12 items using a five point Likert scale. A total of 211 customers completed and returned the questionnaire. However, Multiple Regression Analysis and the Kruskal Wallis Test were employed for the purpose of data analysis.

\section{Logistics Service Quality (LSQ)}

\section{Literature Review}

LSQ concept was promoted by [15], which emphasized the fact that the customers perception on LSQ is not only oriented towards the physical distribution, being especially related to the after-sales process. LSQ is the result received comparing customers' expectations with customers' perception of service quality. Clients, prior to ordering the service, already have expectations of what the service provider should offer them. Therefore the quality of logistical service perceived by the client is the difference between the perceived service and expectation [16]. According to the opinions of the specialists [17; 18], LSQ is determined by the following factors: customers' perception of the after-sales services, quality and relevance of information provided by sales and customer care representatives, order and delivery procedures [19] proposed a modified version of the LSQ pattern, taking into consideration the elements which assure the logistic processes quality (procedures, information, after-sales communication), on the one hand, and the elements which provide logistic service accuracy, on the other hand.

Furthermore, [20] considers that a scale that measures LSQ must be focused on information regarding the customers' perception on the operational side of the ordering and delivery processes. Recent studies in LSQ field emphasize the fact that the personalized relationships among sales representatives and customers determine a favourable perception on the qualitative level of the logistic function [21; 22]. The option for e-commerce involves a logistic system tailored to the customers' requirements, reflecting the flexibility of the ordering system, speed of delivery and customization of products and services provided online [Mărunţelu, 23].

\section{Customer Satisfaction}

The satisfaction construct has been conceptualized, measured and tested for decades in the literature in various industries and contexts $[24 ; 25]$. Usually authors use the confirmation of expectations as the basis for the operational definition of the satisfaction construct. The satisfaction construct can be classified as transactional or accumulated. The transactional dimension is the perception of the performance of most recent transaction [26]. Other authors such as [27], however, assert that satisfaction should be viewed as a judgment based on experience regarding a particular product or service.

Thus, customer satisfaction depends on various factors such as the perceived quality of service, customer mood, emotion, social interaction, customers' associates' experience and other specific subjective factors [28]. Most research findings indicate that to increase the level of customer satisfaction organizations should provide a high level of service quality as service quality is normally considered an antecedent of customer satisfaction [29]. 


\section{Results And Discussion}

Characteristics

Table 1: Demographic Profile of the Respondents

Sex
Frequency
Percentage $(\%)$

Male:

Female:

95

45.02

54.98

Age group

$\begin{array}{lll}18-24 & 73 & 34.60 \\ 25-34 & 55 & 26.07 \\ 36-44 & 51 & 24.17 \\ 45-\text { others } & 32 & 15.16\end{array}$

Source: Author's Computation (2017).

Table 2: Model Summary ${ }^{\mathrm{b}}$

\begin{tabular}{|c|c|c|c|c|c|c|}
\hline Model & $\mathrm{R}$ & R Square & $\begin{array}{l}\text { Adjusted R } \\
\text { Square }\end{array}$ & $\begin{array}{l}\text { Std. Error of the } \\
\text { Estimate }\end{array}$ & $F$ & Sig. \\
\hline 1 & $.617^{\mathrm{a}}$ & .381 & .363 & .716 & 20.999 & $.000^{\mathrm{a}}$ \\
\hline
\end{tabular}

a. Predictors: (Constant), product prices, shipping fee, order fulfillment, delivery speed, reliability, quality of products

b. Dependent Variable: customer satisfaction

Source: Author's Computation (2017).

Table 3: Coefficients $s^{a}$

\begin{tabular}{|c|c|c|c|c|c|c|}
\hline \multirow{2}{*}{\multicolumn{2}{|c|}{ Model }} & \multicolumn{2}{|c|}{ Unstandardized Coefficients } & \multirow{2}{*}{$\begin{array}{c}\begin{array}{c}\text { Standardized } \\
\text { Coefficients }\end{array} \\
\text { Beta }\end{array}$} & \multirow[b]{2}{*}{$\mathrm{T}$} & \multirow[b]{2}{*}{ Sig. } \\
\hline & & B & Std. Error & & & \\
\hline \multirow[t]{7}{*}{1} & (Constant) & -.204 & .552 & & -.370 & .712 \\
\hline & Delivery speed & .203 & .067 & .168 & 3.043 & .003 \\
\hline & Shipping fee & .098 & .044 & .134 & 2.208 & .028 \\
\hline & Product prices & .102 & .045 & .140 & 2.266 & .025 \\
\hline & Reliability & .216 & .068 & .179 & 3.166 & .002 \\
\hline & Order fulfillment & .452 & .069 & .429 & 6.559 & .000 \\
\hline & Quality of products & .349 & .080 & .261 & 4.333 & .000 \\
\hline
\end{tabular}

a. Dependent Variable: customer satisfaction

Source: Author's Computation (2017).

The regression model in TABLE 3 explains only $38.1 \%$ of the variance in logistics service quality influencing customer satisfaction in the online retailing business in Nigeria. Thus, all the variables in the model provided only $61.7 \%$ of level of explanation. This is statistically significant as it was confirmed in TABLE 2 by F-value of 20.999 that is significant at $\mathrm{p}<0.05$. Hence, the hypothesis that logistics service quality has a significant impact customer satisfaction is accepted. Again, from table 3, order fulfillment has the highest significant contribution of $42.9 \%$ while the other variables quality of products, reliability, delivery speed, and product prices all made a significant contribution although shipping fee although shipping fee made the least contribution. 


\section{Kruskal-Wallis Test}

Table 4: Ranks

\begin{tabular}{|ll|r|r|}
\hline & $\begin{array}{l}\text { Level of } \\
\text { Satisfactio } \\
\mathrm{n}\end{array}$ & $\mathrm{N}$ & Mean Rank \\
\hline Customer satisfaction & 1 & 23 & 95.43 \\
& 2 & 31 & 78.58 \\
& 3 & 56 & 102.55 \\
& 4 & 64 & 113.55 \\
& 5 & 37 & 127.69 \\
& Total & 211 & \\
\hline
\end{tabular}

Source: Author's Computation (2017).

Table 5: Test Statistics ${ }^{a, b}$

\begin{tabular}{|l|r|}
\hline & \multicolumn{1}{|c|}{$\begin{array}{c}\text { Customer } \\
\text { satisfaction }\end{array}$} \\
\hline Chi-Square & 14.395 \\
Df & 4 \\
Asymp. Sig. & .006 \\
\hline
\end{tabular}

a. Kruskal Wallis Test

b. Grouping Variable: Level of

satisfaction

Source: Author's Computation (2017).

The results from TABLE 5 suggests that there is a significant difference in the customer satisfaction level across the different online retailing stores with a Chi-square value of 14.395 at $p \leq .01$. An inspection of the mean ranks for the online stores suggests that the customers were highly satisfied irrespective of the choice of online store they purchased from.

Furthermore, as stated by the respondents the challenges encountered mostly are the difficulty associated with online payment at times and the risk of card fraud, although e-tailers allow customers to pay cash on delivery, which however is also limited to specific locations within the countries notably Lagos, PortHarcourt and Abuja. Again, some noted that the shipping fee somewhat seem rather exorbitant when more orders are placed with different sellers on the online shop as compared to visiting a traditional store.

\section{Conclusion}

Empirically, the results obtained clearly indicate very strong impact of logistics service quality on customer satisfaction. However, because of the complexity of the considered problems, further research becomes imperative. First, the sample considered is limited to prominent online stores and certain number of customers. In order to make it representative, the sample has to be expanded to other online stores, as well as to different customers and market segments. Second, besides the operational LSQ dimensions considered in this study, it is necessary to simultaneously observe impact of the relational dimensions of LSQ on customer satisfaction. Nevertheless, the author considers the results of this study as a contribution to knowledge and a good base for further researches of the problem mentioned.

\section{References}

[1]. K. Chen, C. Chang, and C. Lai, Service quality gaps of business customers in the shipping industry. Transportation Research Part E, 45, 2009, 222-237. http://dx.doi.org/10.1016/j.tre.2008.02.005

[2]. L. Wang, Research on the impact of e-commerce to logistics economy: An empirical analysis based on Zhengzhou Airport logistics. International Journal of Security and Its Applications, 9(10), 2015, 275-286

[3]. R. L. A. Oliver, Cognitive model of the antecedents and consequences of satisfaction decisions. Journal of Marketing Research, 17( 180), 1980, 460-469

[4]. A. Parasuraman, V. A. Zeithaml, and L. L. Berry, A conceptual model of service quality and its implications for future research, Journal of Marketing, 49(Fall), 1985, 41-50.

[5]. B. Davis-Sramek, J. T. Mentzer, and T. P. STANK, Creating consumer durable retailer customer loyalty through order fulfillment service operations, Journal of Operations Management, 26, 2008, 781-797.

[6]. L. Wang, Research on the impact of e-commerce to logistics economy: An empirical analysis based on Zhengzhou Airport logistics. International Journal of Security and Its Applications, 9(10), 2015, 275-286 
[7]. K. Harris, R. Harris, and S. Baron, Customer participation in retail service: Lessons from Brecht, International Journal of Retail \& Distribution Management, 29(8), 2001, 359-369.

[8]. D. J. Flint, R. F. Lusch, and S. L. Vargo, The supply chain management of shopper marketing as viewed through a service ecosystem lens, International Journal of Physical Distribution \& Logistics Management, 44(1/2), 2014, 23-38.

[9]. K. L. Granzin, J. J. Painter, and E. K. Valentin, Consumer logistics as a basis for segmenting retail markets: An exploratory inquiry, Journal of Retailing and Consumer Services, 4(2), 1997, 99-107.

[10]. C. Teller, H. Kotzab, and D. B. Grant, The consumer direct services revolution in grocery retailing: An exploratory investigation, Managing Service Quality, 16(1), 2006, 78-96.

[11]. C. Teller, H. Kotzab, and D. B. Grant, The relevance of shopper logistics for consumers of store-based retail formats, Journal of Retailing and Consumer Services, 19(1), 2012, 59-66.

[12]. D. B. Grant, Logistics management ( London: Pearson Education, 2012)

[13]. Q, Zhang, M. A. Vonderembse, and J. S. Lim, Logistics flexibility and its impact on customer satisfaction, International Journal of Logistics Management, 16(1), 2005, 71-95.

[14]. D. B. Grant, UK and US management styles in logistics: Different strokes for different folks? International Journal of Logistics: Research and Applications, 7(3), 2004, 181-197.

[15]. J. T. Mentzer, D. J. Flint, and T. M. Hult, Logistics service quality as segment-customized process. Journal of Marketing, 65(4), 2001, 82- 104. http://dx.doi.org/10.1509/jmkg.65.4.82.18390

[16]. D. F. Campos, and K. C. No'brega, Importance and the zone of tolerance of customer expectations of fast food services. Journal of Operations and Supply Chain Management, 20092 (2), 56-71.

[17]. J. T. Mentzer, D. J. Flint, and T. M. Hult, Logistics service quality as segment-customized process. Journal of Marketing, 65(4), 2001, 82- 104. http://dx.doi.org/10.1509/jmkg.65.4.82.18390

[18]. M. Rafiq, and H. S. Jaafar, Measuring customers' perceptions of logistics service quality of 3PL service providers, Journal of Business Logistics, 28(2), 2007, 159-175. http://dx.doi.org/10.1002/j.2158-1592.2007.tb00062.x

[19]. C. C. Bienstock, M. B. Royne,D. Sherrell, and T. F. Stafford, An expanded model of logistics service quality: Incorporating logistics information technology, International Journal of Production Economics, 113 (1), 2008, 5-22.

[20]. 20] I. Gil-Saura, M. E. Ruiz-Molina, and D. Servera-Francés, Logistic Service Quality and Technology: A Comparison between Supplier-retailer and Retailer-consumer Relationships, The International Review of Retail, Distribution and Consumer Research, 18 (5), 2008, 495-510.

[21]. P. Vesel, and V. Zabkar, Relationship quality evaluation in retailers' relationships with consumers, European Journal of Marketing, 44, 2010, 1334-1365.

[22]. N. A. Omar, and R. Musa, Measuring service Qquality in retail loyalty programmes (LPSQual): Implications for retailers' retention strategies, International Journal of Retail \& Distribution Management, 39(10), 2011, 759 - 784.

[23]. I, Mărunţelu, The particularities of logistics related to ecommerce. Amfiteatru Economic, (24), 2008, $177-191$.

[24]. 24] R. L. A. Oliver, Cognitive model of the antecedents and consequences of satisfaction decisions. Journal of Marketing Research, 17( 180), 1980, 460-469.

[25]. 25] A. Parasuraman, V. A. Zeithaml, and L. L. Berry, A conceptual model of service quality and its implications for future research, Journal of Marketing, 49(Fall), 1985, 41-50.

[26]. R. L, OLIVER, Cognitive, affective, and attribute bases of the satisfaction response, Journal of Consumer Research, 20, 1993, 418430 .

[27]. E. W. Anderson, C. Fornell, and D. R. Lehmann, Customer satisfaction, market share, and profitability: Findings from Sweden, Journal of Marketing, 58(3), 1994, 53-67.

[28]. I. Meidutè-Kavaliauskienėa, A. Aranskisa, and M. Litvinenkoa, Consumer satisfaction with the quality of logistics services, Procedia - Social and Behavioral Sciences, 110, 2013, 330-340.

[29]. I. Gil-Saura, D. S. Frances, G. B. Contri, and M. F. Blasco, Logistics service quality: a new way to loyalty, Industrial Management \& Data Systems, 108(5), 2008, 650-668 